\title{
Effects of Early Phosphorus Intake on Respiratory Distress in Extremely Low-Birth-Weight Infants
}

Hye Jung Bae ${ }^{1, *}$, Hyung Woo Yoon ${ }^{1, *}$, Moon Jin $\mathrm{Kim}^{1}$, Ae Hee Jung ${ }^{1}$, Sun Hoi Jung ${ }^{1}$, Hyeon Joo Hahn ${ }^{1}$, Yun Hee Jo ${ }^{1}$, Yoon Sook Cho ${ }^{1}$, Ee-Kyung Kim², Seung Han Shin ${ }^{2}$, In Gyu Song ${ }^{3}$, and Seung Hyun Shin ${ }^{2}$

${ }^{1}$ Department of Pharmacy, Seoul National University Hospital, Seoul, Korea

${ }^{2}$ Department of Pediatrics, Seoul National University Children's Hospital, Seoul, Korea

${ }^{3}$ Cancer Hospice Center, National Cancer Center, Goyang, Korea

\section{ABSTRACT}

Purpose: This study was aimed to investigate the effect of early phosphorus intake on respiratory distress in extremely low-birth-weight infants (ELBWIs) with a high incidence of hypophosphatemia.

Methods: We performed a retrospective study to target 164 ELBWIs admitted to the neonatal intensive care unit in Seoul National University Children's Hospital. Birth characteristics, nutritional intake, and electrolyte levels during the first week were investigated as predictors that would affect the clinical outcomes. The correlations among invasive ventilation at postnatal age of 2 weeks, moderate-to-severe bronchopulmonary dysplasia (BPD), and phosphorous intake were analyzed.

Results: Hypophosphatemia (phosphorus level $<4 \mathrm{mg} / \mathrm{dL}$ ) was observed in $72.0 \%$ of the subjects. The rates of invasive ventilation $(P=0.001)$ and moderate-to-severe BPD $(P=0.005)$ were significantly lower in the high phosphorus intake group $(\geq 0.7 \mathrm{mM}$ / $\mathrm{kg} /$ day) than in the low phosphorus intake group $(<0.7 \mathrm{mM} / \mathrm{kg} /$ day). Phosphorus intake during the first week was a significant factor affecting invasive ventilation at 2 weeks of age (adjusted odds ratio [OR], 8.212; 95\% confidence interval [CI], 2.256 to 28.896; $P=0.001$ ) and moderate-to-severe BPD (adjusted OR, 3.402; 95\% CI, 1.274 to 9.084; $P=0.015)$.

Conclusion: Early insufficient phosphorus intake confers a significantly higher risk with invasive ventilation at 2 weeks of age and moderate-to-severe BPD. Therefore, early sufficient phosphorus supply may improve respiratory outcomes in ELBWIs.

Key Words: Infant, extremely low birth weight; Phosphorus; Respiratory distress; Bronchopulmonary dysplasia

\section{서론}

신생아 집중치료의 발전으로 최근에는 더욱 최적화된 영양수액 요법에 대한 연구들이 활발 하게 진행되고 있다. 미숙아들은 출생 직후 일시적인 영양공급의 중단에 의해 대사적인 변화와
Received: 2 March 2019

Revised: 10 July 2019

Accepted: 18 July 2019

Correspondence to: Ee-Kyung Kim

Department of Pediatrics, Seoul National University Children's Hospital, 101 Daehak-ro, Jongno-gu, Seoul 03080, Korea

Tel: +82-2-2072-3628

Fax: +82-2-743-3455

E-mail: kimek@snu.ac.kr

https://orcid.org/0000-0002-7063-168X

*Hye Jung Bae and Hyung Woo Yoon contributed equally to this study as first authors.

Copyright(c)

By Korean Society of Neonatology.

All right reserved.

This is an Open-Access article distributed under the terms of the Creative Commons Attribution Non-Commercial License (http://creativecommons.org/licenses/ by-nc/4.0), which permits unrestricted non-commercial use, distribution, and reproduction in any medium, provided the original work is properly cited. 
체중 감소를 동반한 현저한 전해질의 불균형을 겪으며 이러한 특징 들은 특히 출생 첫 1 주일 이내에 두드러진다. 최근 연구들에서는 출 생 후 정맥영양지원을 받는 초극소 저체중출생아(extremely lowbirth-weight infants, ELBWIs)들에게서 생후 첫 1주 이내에 저인산 혈증(hypophosphatemia)이 자주 동반된다고 보고하고 있으며 동 일 재태 연령에 비해 몸무게가 작게 나가는 부당경량아(small for gestational age, SGA)일수록 그 경향성이 높다고 보고하고 있다 ${ }^{1-3)}$.

인(phosphorus, $\mathrm{P}$ )은 세포의 기능과 골격에 필수적인 원소로서 세포 성장과 골 성장이 빠른 신생아에게서 그 요구량이 더욱 많으며 일반적으로 신생아에서 혈청 P 농도가 성인보다 높다. 신생아의 경 우 일반적으로 혈청 P 농도 $4 \mathrm{mg} / \mathrm{dL}$ 미만을 저인산혈증으로 정의하 나, 미숙아에서의 저인산혈증의 기준을 $2.0-5.5 \mathrm{mg} / \mathrm{dL}$ 범위로 다양 하게 제시하고 있고, 임상적으로 영향을 미치는 기준에 대해서는 명 확하지 않다 ${ }^{1-5)}$. 또한, 실제로 측정된 혈청 P 수치가 임상적 증상과 항상 연관성을 보이는 것은 아니며, 체내 $\mathrm{P}$ 의 결핍을 정확히 반영해 주지 못한다는 한계점이 있다, ${ }^{6,7)}$.

$\mathrm{P}$ 는 세포 내의 에너지 대사, 효소반응, 혈색소의 산소해리 등 인체 내에서 많은 작용을 하기 때문에 결핍이 생기면 다양한 임상증상이 발생할 수 있다. 대표적인 증상으로는 호흡부전, 심장수축력의 저 하, 횡문근융해증, 적혈구의 용혈, 백혈구의 식탐능 저하, 구루병 등 이 있다 ${ }^{4,677}$.

저인산혈증은 refeeding syndrome에서 나타나는 가장 대표적인 증상으로 호흡근의 약화를 유발하여 급성호흡부전에 영향을 준다고 알려져 있다 ${ }^{6,7)}$. Refeeding syndrome이란 기아 상태에서 급격한 영 양 재공급 시 발생하는 대사적인 반응으로, 인슐린의 분비가 촉진되 면 세포의 동화작용(anabolism)에 필요한 칼륨(potassium, K), P, 마 그네슘(magnesium, $\mathrm{Mg}$ )이 세포 내로 이동하면서 이로 인해 전해질 의 불균형이 유발된다 ${ }^{8)}$.

중환자실 환자에서 저인산혈증이 동반하는 여러 가지 치명적인 합병증들이 보고되고 있으며 ${ }^{6,7,9,10)}$ 저인산혈증이 미숙아의 임상적 인 예후에 미치는 영향을 다룬 연구 중에선 저인산혈증이 신생아 패혈 증의 위험도를 높인다는 보고도 있다 ${ }^{11)}$. ELBWIs에게 발생하는 저인산 혈증을 refeeding syndrome 유사현상으로 설명하고 있는 연구들이 있으며 ${ }^{1,512)}$ 실제로 P 부족이 정맥영양지원을 받는 미숙아들에게 임 상적으로 어떤 영향을 주는지에 대해선 아직 많은 연구가 필요하다.

이에 본 연구는 출생 초기의 P 공급량이 ELBWIs에서의 호흡곤란 에 어떤 영향을 미치는지에 대하여 알아보고, ELBWIs에서의 적절한 정맥영양 계획을 위한 근거를 마련하고자 하였다.

\section{대상 및 방법}

\section{1. 연구 대상}

2010년 9월부터 2016년 8월까지 서울대학교병원에서 출생하여 신 생아 중환자실에 입원한 재태 연령(gestational age) 30 주 미만이며 출생체중 $1 \mathrm{~kg}$ 미만의 정맥영양지원을 받는 신생아들을 대상으로 연 구를 하였다. 이 중 (1) 2 주일 이내 사망한 경우, (2) 선천성 대사질환 이 있는 경우, (3) 선천성 심장기형이 있는 경우는 제외하였다.

\section{2. 연구 방법}

환자의 전자의무기록(electronic medical records) 분석을 통하여 임상적 결과(호흡곤란)에 영향을 줄 것으로 예상되는 인자들을 조사 하였다. 환자의 임상적인 변수로는 재태 연령, 성별, 출생체중, 출생 신장, 출생 두위(head circumference), 5 분 Apgar score, clinical risk index for babies (CRIB) II score, 산전 스테로이드 복용 여부, 분만 방식, 동맥관개존증(patent ductus arteriosus, PDA) 치료 여부, 폐계 면활성제(surfactant) 사용 여부, 생후 1일 내 기계환기 여부, 융모양 막염, SGA 여부 등을 조사하였다. PDA 치료 여부는 약물을 투여하 거나 수술을 한 경우로 정의하였다. SGA는 Fenton growth chart를 확인하였으며, weight for age가 $10 \%$ 미만인 경우로 정의하였다 ${ }^{13)}$. 환자의 영양적 인자로는 생후 일주일간의 평균 열량, 단백질 공급 량을 조사하였고, 정맥 및 경장영양을 통한 칼슘(calcium, Ca), P 공 급량을 조사하였다. 혈액학적인 인자로는 생후 일주일 동안 측정된 혈청 $\mathrm{Ca}, \mathrm{P}, \mathrm{K}$ 수치의 평균값, 생후 일주일 내 측정된 최저 혈청 P 수 치, 생후 일주일 동안 측정된 소변량(urine output)의 평균, 생후 4-7 일 기간의 최대 serum creatinine 등을 조사하였다. 예후를 평가하 기 위한 임상적인 인자로는 1 차 결과변수로 생후 2 주에서의 침습적 환기 여부를 조사하였고, 2 차 결과변수로 중등도 이상의 기관지 폐 이형성증(bronchopulmonary dysplasia, BPD)과 퇴원 시까지 생존 여부를 조사하였다. BPD는 National Institutes of Child Health and Human Development Neonatal Research Network (NICHD) 정의 에 따라 분류하였다 ${ }^{14)}$. P 공급량은 receiver operating characteristic curve를 통해 cut off value를 정하였고, high P 공급군과 low P 공급 군으로 나누어 임상적 결과에 미치는 영향을 비교하였다. P 공급량 에 따른 생후 2 주에서의 침습적 환기 여부와 중등도 이상의 $\mathrm{BPD}$ 발 생률을 비교하였으며, 생후 1 일 내 기계환기 여부에 따라 그룹을 나 누어 하위그룹 분석을 시행하였다.

\section{3. 영양공급 protocol}

정맥영양의 공급은 서울대학교어린이병원 신생아중환자실의 protocol에 따라 첫날 60-70 mL/kg로 시작하여 1주일경 120-150 $\mathrm{mL} / \mathrm{kg}$ 에 도달하도록 하였다. 포도당 투여속도(glucose infusion rate, GIR)는 첫날 4-6 mg/kg/min으로 시작하여 목표 GIR 12-15 
$\mathrm{mg} / \mathrm{kg} / \mathrm{min}$ 까지 점차 증량하였으며 혈당을 모니터링하면서 조절하 였다. 단백질은 $10 \%$ Primene (Baxter Korea, Seoul, Korea)으로써 공 급량은 첫날 $1.5-2.0 \mathrm{~g} / \mathrm{kg}$ 로 시작하여 목표 $4.0 \mathrm{~g} / \mathrm{kg}$ 으로 점차 증량하 였다. 지방은 20\% SMOFlipid (Fresenius Kabi Korea, Seoul, Korea) 로써 첫날 $1.0 \mathrm{~g} / \mathrm{kg}$ 로 시작하여 목표 $3.0 \mathrm{~g} / \mathrm{kg}$ 으로 점차 증량하였다. $\mathrm{Ca}$ 는 $\mathrm{Ca}$ gluconate로서 첫날부터 공급하였다. 나트륨(sodium, $\mathrm{Na}$ ), $\mathrm{K}, \mathrm{P}$ 는 소변량을 확인한 뒤에 출생 후 2-3일 후부터 공급하였다. 조 사 기간 동안의 거대영양소(macronutrients)와 전해질의 공급량은 환 자의 혈액학적 검사 결과를 참고하여 nutrition support team (NST) 자문 및 주치의 판단에 따라 조절되었다. 경장영양은 출생체중에 따 라 첫 3-5일간 trophic feeding 수준으로 공급되었고 이후 tolerance 에 따라 10-20 mL/kg/day 씩 점차 증량하였다.

\section{4. 분석방법}

통계프로그램은 IBM SPSS statistics version 25 (IBM Co., Armonk, $\mathrm{NY}, \mathrm{USA}$ )를 이용하였다. 생후 일주일 평균 P 공급량에 따른 호흡곤 란의 예후를 비교하기 위해 교차분석(chi-square test 또는 Fisher's exact test) 및 독립표본 T검정을 시행하였다. 단백질 공급량과 $\mathrm{P}$ 수 치와의 상관관계를 확인하기 위해 Pearson's correlation 분석을 시행 하였다. 교란변수(재태 연령, 출생체중 등)를 통제하고 임상적 결과 에 미치는 여러 인자들의 연관성을 파악하기 위해 다변량 로지스틱 회귀분석(logistic regression analysis)을 시행하였다. $P<0.05$ 인 경우 를 통계적으로 유의한 것으로 판정하였다.

본 연구는 후향적 데이터분석 연구로 연구자의 동의서 취득이 면 제되며, 서울대학교병원 임상시험심사위원회의 승인 하에 시행되
었다(IRB No. H-1609-105-793).

\section{결과}

\section{1. 환자의 기본 정보 및 임상적 특성}

2010년 9월부터 2016년 8월까지 서울대학교어린이병원에서 출생 하여 신생아중환자실에 입실한 재태 연령 30 주 미만, 출생체중 $1 \mathrm{~kg}$ 미만의 ELBWIs 중 정맥영양지원을 받은 환자는 총 177 명이었으며, 제외 기준에 해당하는 환자 13 명을 제외하고 164 명의 환자가 연구 에 포함되었다. 대상 환자의 기본 정보 및 임상적 특성은 Tables 1,2 와 같다.

대상 환자의 평균 재태 연령은 26.3 주 \pm 1.7 주, 평균 출생체중은 $754.2 \pm 159.5 \mathrm{~g}, \mathrm{SGA}$ 는 31명(18.9\%)이었다. 대상 환자의 정맥영양 공급량은 1 주일 평균 열량이 $57.8 \pm 10.8 \mathrm{kcal} / \mathrm{kg} / \mathrm{day}$, 평균 단백질 공급량이 $2.4 \pm 0.5 \mathrm{~g} / \mathrm{kg} / \mathrm{day}$, 평균 P 공급량이 $0.6 \pm 0.3 \mathrm{mM} / \mathrm{kg} / \mathrm{day}$ 이었다. 경장영양을 통한 평균 P 공급량은 $0.03 \pm 0.08 \mathrm{mM} / \mathrm{kg} / \mathrm{day}$ 였 다. 대상 환자의 생후 1 주일 평균 혈청 P 수치는 $4.9 \pm 1.0 \mathrm{mg} / \mathrm{dL}$, 생 후 1 주일 평균 소변량은 $2.9 \pm 0.8 \mathrm{~mL} / \mathrm{kg} / \mathrm{hr}$, 생후 1 주일 내 측정된 가 장 낮은 혈청 $\mathrm{P}$ 수치의 평균은 $3.3 \pm 1.2 \mathrm{mg} / \mathrm{dL}$ 였고 저인산혈증 $(P<4$ $\mathrm{mg} / \mathrm{dL}$ )이 발생한 환자는 118 명으로 전체의 $72.0 \%$ 에 해당하였다.

$\mathrm{P}$ 공급량 $0.7 \mathrm{mM} / \mathrm{kg} / \mathrm{day}$ 를 기준으로 high P 공급군과 low P 공 급군으로 나누어 비교하였을 때, high P 공급군에서 재태 연령이 더 높고 제왕절개로 태어난 비율이 더 높았으며, 생후 1 일 내 기계환기 여부와 PDA 치료 비율, 생후 4-7일 기간의 최대 serum creatinine은

Table 1. Clinical Characteristics of the Study Population

\begin{tabular}{|c|c|c|c|c|}
\hline Characteristic & $\begin{array}{l}\text { Total patients } \\
\quad(n=164)\end{array}$ & $\begin{array}{c}\text { High P intake } \\
(\geq 0.7 \mathrm{mM} / \mathrm{kg} / \mathrm{d})(\mathrm{n}=63)\end{array}$ & $\begin{array}{c}\text { Low P intake } \\
(<0.7 \mathrm{mM} / \mathrm{kg} / \mathrm{d})(\mathrm{n}=101)\end{array}$ & $P$-value \\
\hline Gestational age (wk) & $26.3 \pm 1.7$ & $26.7 \pm 1.6$ & $26.0 \pm 1.7$ & 0.006 \\
\hline Birth weight (g) & $754.2 \pm 159.5$ & $776.8 \pm 158.6$ & $740.0 \pm 159.1$ & 0.151 \\
\hline 5 min Apgar score $(n=61 / 99)$ & $5.4 \pm 1.9$ & $5.4 \pm 2.1$ & $5.4 \pm 1.9$ & 0.878 \\
\hline CRIB II score & $11.6 \pm 2.6$ & $11.1 \pm 2.4$ & $11.9 \pm 2.7$ & 0.061 \\
\hline Male sex & $77(47.0)$ & $35(55.6)$ & $42(41.6)$ & 0.081 \\
\hline Prenatal steroid & $108(65.9)$ & $39(61.9)$ & $69(68.3)$ & 0.400 \\
\hline Chorioamnionitis & $83(50.6)$ & $27(42.9)$ & $56(55.4)$ & 0.117 \\
\hline Surfactant administration & $132(80.5)$ & $48(76.2)$ & $84(83.2)$ & 0.273 \\
\hline Intubation (1st d) & $147(89.6)$ & $52(82.5)$ & $95(94.1)$ & 0.019 \\
\hline SGA & $31(18.9)$ & $16(25.4)$ & $15(14.9)$ & 0.093 \\
\hline
\end{tabular}

Values are expressed as mean \pm standard deviation or number (\%).

Abbreviations: CRIB, clinical risk index for babies; CS, cesarean section; SGA, small for gestational age; PDA, patent ductus arteriosus; SCr, serum creatinine; PNA, postnatal age. 
low P 공급군에서 더 높았다. 영양 공급량에서는 high P 공급군이 더 많은 열량과 단백질, $\mathrm{Ca}$ 및 $\mathrm{P}$ 를 공급받았으며, 생후 1 주일간 평균 혈청 $\mathrm{P}$ 수치와 초기 혈청 $\mathrm{P}$ 수치는 더 낮게 나타났다.

생후 1 주일간의 평균 단백질 공급량과 평균 $\mathrm{P}$ 농도는 유의한 음의 상관관계를 나타내었다(Pearson 상관계수 $-0.153 ; P=0.050$ ).

\section{P 공급량 및 수치에 따른 임상적 결과}

$\mathrm{P}$ 의 공급량에 따른 호흡곤란의 예후를 비교하기 위한 교차분석 시행 결과(Table 3), 생후 2주까지 침습적 환기가 필요했던 환자는 high P 공급군 63명 중 30명(47.6\%), low P 공급군 101명 중 73명 (72.3\%)으로 high P 공급군에서 유의하게 낮았다 $(P=0.001)$. 생후 1 일 내 기계환기를 적용한 환자 대상 $(n=147)$ 으로 하위그룹 분석을 시 행한 경우에도 생후 2 주 침습적 환기가 필요한 환자의 비율이 high $\mathrm{P}$ 공급군에서 유의하게 낮았다 $(P=0.015)$. 퇴원 시까지의 사망률은 high P 공급군에서 5명(7.9\%), low P 공급군에서 11명(10.9\%)으로 low P 공급군에서 더 높게 나타났으나 통계적으로 유의하지 않았다 $(P=0.535)$.

생존자 148 명을 대상으로 중등도 이상의 $\mathrm{BPD}$ 를 비교하였을 때, high P 공급군에서 53.4\% (31/58), low P 공급군 75.6\% (68/90)로 high P 공급군에서 $\mathrm{BPD}$ 비율이 유의하게 낮았다 $(P=0.005)$. 생후 1 일 내 기계환기를 적용한 환자 대상 $(n=131)$ 으로 하위그룹 분석을 시 행한 경우에도 중등도 이상의 BPD 발생 비율이 high P 공급군에서 유의하게 낮았다 $(P=0.013)$.

한편, 생후 1주일간 최소 P 수치가 $2 \mathrm{mg} / \mathrm{dL}$ 미만인 군과 $2 \mathrm{mg} / \mathrm{dL}$ 이상인 군을 나누어 비교하였을 때, 생후 2 주 침습적 환기 의존도 는 $17 / 27$ (63.0\%) 대 86/137 (62.8\%)으로 유의한 차이를 보이지 않 았다 $(P=0.985)$. 중등도 이상의 $\mathrm{BPD}$ 에서도 $16 / 23(69.6 \%)$ 대 83/125 (66.4\%)으로 통계적으로 유의한 차이를 보이지 않았다 $(P=0.767)$.

Table 2. Nutritional Intake and Laboratory Data of the Study Population

\begin{tabular}{|c|c|c|c|c|}
\hline First postnatal week & $\begin{array}{l}\text { Total patients } \\
\quad(\mathrm{n}=164)\end{array}$ & $\begin{array}{c}\text { High P intake } \\
(\geq 0.7 \mathrm{mM} / \mathrm{kg} / \mathrm{d})(\mathrm{n}=63)\end{array}$ & $\begin{array}{c}\text { Low P intake } \\
(<0.7 \mathrm{mM} / \mathrm{kg} / \mathrm{d})(\mathrm{n}=101)\end{array}$ & $P$-value \\
\hline Average calorie $(\mathrm{kcal} / \mathrm{kg} / \mathrm{d})^{*}$ & $57.8 \pm 10.8$ & $62.6 \pm 9.1$ & $54.7 \pm 10.7$ & $<0.001$ \\
\hline Average protein $(\mathrm{g} / \mathrm{kg} / \mathrm{d})^{*}$ & $2.4 \pm 0.5$ & $2.6 \pm 0.4$ & $2.3 \pm 0.5$ & $<0.001$ \\
\hline Average urine output $(\mathrm{mL} / \mathrm{kg} / \mathrm{hr})$ & $2.9 \pm 0.8$ & $3.0 \pm 0.7$ & $2.8 \pm 0.8$ & 0.167 \\
\hline Average P intake $(\mathrm{mM} / \mathrm{kg} / \mathrm{d})^{*}$ & $0.6 \pm 0.3$ & $0.9 \pm 0.2$ & $0.4 \pm 0.2$ & $<0.001$ \\
\hline Average Ca intake $(\mathrm{mEq} / \mathrm{kg} / \mathrm{d})^{*}$ & $1.4 \pm 0.5$ & $1.5 \pm 0.5$ & $1.3 \pm 0.5$ & 0.013 \\
\hline Average serum P level (mg/dL) & $4.9 \pm 1.0$ & $4.6 \pm 1.1$ & $5.1 \pm 0.9$ & 0.005 \\
\hline Average serum Ca level (mg/dL) & $9.2 \pm 0.6$ & $9.3 \pm 0.7$ & $9.2 \pm 0.6$ & 0.361 \\
\hline Average serum Klevel (mEq/L) & $5.0 \pm 0.7$ & $5.1 \pm 0.7$ & $5.0 \pm 0.7$ & 0.558 \\
\hline Lowest serum P level (mg/dL) & $3.3 \pm 1.2$ & $3.3 \pm 1.2$ & $3.4 \pm 1.2$ & 0.590 \\
\hline Initial serum P level (mg/dL) & $6.2 \pm 1.3$ & $5.8 \pm 1.2$ & $6.5 \pm 1.3$ & 0.002 \\
\hline Hypophosphatemia $^{\dagger}$ & $118(72.0)$ & $46(73.0)$ & $72(71.3)$ & 0.811 \\
\hline
\end{tabular}

Values are expressed as mean \pm standard deviation or number (\%).

${ }^{*}$ Parenteral nutrition intake; ${ }^{\dagger}$ Hypophosphatemia $=\mathrm{P}<4 \mathrm{mg} / \mathrm{dL}$.

Table 3. Comparison of Respiratory Outcomes between Patients with High Phosphorus Intake vs. Low Phosphorus Intake

\begin{tabular}{lccc}
\hline Variable & High P intake $(\geq 0.7 \mathrm{mM} / \mathrm{kg} / \mathrm{d})$ & Low P intake $(<0.7 \mathrm{mM} / \mathrm{kg} / \mathrm{d})$ & $P$-value \\
\hline Total no. (n=164) & 63 & 101 & $73(72.3)$ \\
Invasive ventilation (at PNA 2 wk) & $30(47.6)$ & $73 / 95(76.8)$ & 0.001 \\
1st day Intubation $(+)(\mathrm{n}=147)$ & $30 / 52(57.7)$ & $0 / 6(0)$ & 0.015 \\
1st day Intubation $(-)(\mathrm{n}=17)$ & $0 / 11(0)$ & $11(10.9)$ & 0.535 \\
Mortality & $5(7.9)$ & $68(75.6)$ & 0.005 \\
Survivors (n=148) & 58 & $67 / 84(79.8)$ & 0.013 \\
Moderate to severe BPD & $31(53.4)$ & $1 / 6(16.7)$ & $1.000^{*}$ \\
1st day Intubation $(+)(\mathrm{n}=131)$ & $28 / 47(59.6)$ & $3 / 11(27.3)$ &
\end{tabular}

Values are expressed as number (\%).

*Moderate to severe BPD, 1st day intubation (-).

Abbreviations: PNA, postnatal age; BPD, bronchopulmonary dysplasia. 


\section{3. 미숙아의 호흡곤란에 영향을 주는 요인}

$\mathrm{P}$ 공급량을 포함하여 호흡곤란에 영향을 미치는 인자에 대해 다변 량 로지스틱 회귀분석을 시행한 결과, 재태 연령이 낮고(<26 weeks), 출생체중이 낮은 경우(<700 g), 계면활성제를 투여한 경우, $\mathrm{P}$ 공급 량이 낮은 경우 $(<0.7 \mathrm{mg} / \mathrm{kg} / \mathrm{day})$ 생후 2주 침습적 환기 의존도가 유의하게 높았다(Table 4). P 공급량의 adjusted odds ratio (OR)은 8.212 (95\% confidence interval [CI], 2.256-28.896; $P=0.001)$ 로 나타 났다.

또한, 출생체중이 낮은 경우 $(<700 \mathrm{~g})$, 남아인 경우, $\mathrm{P}$ 공급량이 낮은 경우 $(<0.7 \mathrm{mg} / \mathrm{kg} / \mathrm{day})$ 중등도 이상의 BPD 발생률이 유의
하게 높았다(Table 5). P 공급량의 adjusted OR은 3.402 (95\% CI, 1.274-9.084; $P=0.015)$ 로 나타났다.

낮은 P 공급량 $(<0.7 \mathrm{mM} / \mathrm{kg} / \mathrm{day})$ 은 재태 연령, 출생체중, 5 분 Apgar score, 성별, 제왕절개, 융모양막염, 폐계면활성제 사용, PDA 치료 여부, 신기능 등의 임상적인 변수와 생후 일주일간의 평균 열량 및 단백질 공급량과 같은 영양학적 인자를 보정하였을 경우에도 미 숙아의 호흡곤란에 영향을 주는 유의한 위험인자로 나타났다.

Table 4. Determinants of Invasive Ventilation More than 2 Weeks after Birth $(n=164)$

\begin{tabular}{lrrrrrr}
\hline Variable & Crude OR & $P$-value & $95 \%$ CI & Adjusted OR & $P$-value & $95 \%$ CI \\
\hline Gestational age $(<26 \mathrm{wk})$ & 30.450 & $<0.001$ & $8.934-103.788$ & 16.539 & $<0.001$ & $3.638-75.192$ \\
Birth weight $(<700 \mathrm{~g})$ & 7.301 & $<0.001$ & $3.158-16.878$ & 5.488 & 0.009 & $1.532-19.656$ \\
5 min Apgar score & 0.628 & $<0.001$ & $0.504-0.781$ & 0.747 & 0.072 & $0.544-1.026$ \\
Male sex & 1.320 & 0.393 & $0.698-2.498$ & 2.847 & 0.058 & $0.965-8.398$ \\
Delivery $(\mathrm{CS})$ & 0.410 & 0.009 & $0.211-0.799$ & 0.480 & 0.218 & $0.150-1.542$ \\
Prenatal steroid & 0.716 & 0.336 & $0.363-1.414$ & 0.471 & 0.178 & $0.157-1.411$ \\
Chorioamnionitis & 2.575 & 0.005 & $1.339-4.951$ & 1.399 & 0.532 & $0.489-4.008$ \\
Surfactant administration & 6.322 & $<0.001$ & $2.681-14.906$ & 6.615 & 0.007 & $1.678-26.081$ \\
PDA treatment & 1.643 & 0.171 & $0.807-3.342$ & 1.240 & 0.719 & $0.384-4.007$ \\
Highest SCr $(\mathrm{PNA} 4-7 \mathrm{~d}, \geq 1.2 \mathrm{mg} / \mathrm{dL})$ & 1.224 & 0.564 & $0.616-2.431$ & 0.284 & 0.037 & $0.087-0.927$ \\
P intake $(<0.7 \mathrm{mM} / \mathrm{kg} / \mathrm{d})$ & 2.868 & 0.002 & $1.484-5.543$ & 8.212 & 0.001 & $2.256-28.896$ \\
Average calorie $(<60 \mathrm{kcal} / \mathrm{kg} / \mathrm{d})$ & 3.598 & $<0.001$ & $1.851-6.993$ & 0.982 & 0.976 & $0.309-3.117$ \\
Average $\operatorname{cotein}(<2.5 \mathrm{~g} / \mathrm{kg} / \mathrm{d})$ & 1.805 & 0.071 & $0.952-3.424$ & 1.014 & 0.981 & $0.317-3.242$ \\
\hline
\end{tabular}

Abbreviations: OR, odds ratio; CI, confidence interval; CS, cesarean section; PDA, patent ductus arteriosus; SCr, serum creatinine; PNA, postnatal age.

Table 5. Determinants of Moderate-to-Severe Bronchopulmonary Dysplasia ( $\mathrm{n}=148)$

\begin{tabular}{|c|c|c|c|c|c|c|}
\hline Variable & Crude OR & $P$-value & $95 \% \mathrm{CI}$ & Adjusted OR & $P$-value & $95 \%$ CI \\
\hline Gestational age $(<26 \mathrm{wk})$ & 3.120 & 0.005 & $1.402-6.943$ & 1.105 & 0.861 & $0.361-3.379$ \\
\hline Birth weight $(<700 \mathrm{~g})$ & 4.607 & 0.001 & $1.886-11.257$ & 3.909 & 0.020 & $1.242-12.301$ \\
\hline 5 min Apgar score & 0.769 & 0.014 & $0.624-0.949$ & 0.904 & 0.432 & $0.703-1.163$ \\
\hline Male sex & 2.067 & 0.043 & $1.023-4.173$ & 3.238 & 0.010 & $1.319-7.948$ \\
\hline Delivery (CS) & 0.862 & 0.675 & $0.431-1.726$ & 0.995 & 0.992 & $0.396-2.505$ \\
\hline Prenatal steroid & 1.282 & 0.505 & $0.618-2.662$ & 1.321 & 0.546 & $0.535-3.266$ \\
\hline Chorioamnionitis & 1.740 & 0.118 & $0.870-3.481$ & 1.367 & 0.506 & $0.544-3.435$ \\
\hline Surfactant administration & 3.225 & 0.005 & $1.427-7.293$ & 2.470 & 0.089 & $0.870-7.012$ \\
\hline PDA treatment & 1.743 & 0.163 & $0.798-3.805$ & 1.519 & 0.429 & $0.539-4.279$ \\
\hline Highest SCr (PNA 4-7 d, $\geq 1.2 \mathrm{mg} / \mathrm{dL}$ ) & 1.051 & 0.896 & $0.501-2.206$ & 0.449 & 0.111 & $0.168-1.201$ \\
\hline P intake $(<0.7 \mathrm{mM} / \mathrm{kg} / \mathrm{d})$ & 2.692 & 0.006 & $1.330-5.449$ & 3.402 & 0.015 & $1.274-9.084$ \\
\hline Average calorie $(<60 \mathrm{kcal} / \mathrm{kg} / \mathrm{d})$ & 3.609 & 0.001 & $1.750-7.445$ & 1.451 & 0.441 & $0.563-3.745$ \\
\hline Average protein $(<2.5 \mathrm{~g} / \mathrm{kg} / \mathrm{d})$ & 2.143 & 0.033 & $1.065-4.312$ & 1.121 & 0.814 & $0.434-2.892$ \\
\hline
\end{tabular}

Abbreviations: OR, odds ratio; CI, confidence interval; CS, cesarean section; PDA, patent ductus arteriosus; SCr, serum creatinine; PNA, postnatal age. 
고찰

본 연구는 출생 초기의 P 공급량이 ELBWIs의 임상적 결과에 미치 는 영향을 알아보고자 하였으며, 신생아중환자실에서 중요시하는 미숙아의 기계환기와 $\mathrm{BPD}$ 에 미치는 영향을 분석하였다. P 공급량 은 미숙아의 호흡곤란에 영향을 주는 유의한 인자로 나타났고, 0.7 $\mathrm{mM} / \mathrm{kg} / \mathrm{day}$ 미만으로 공급 시 기계환기 및 $\mathrm{BPD}$ 발생 비율이 증가될 수 있다.

성인을 대상으로 한 선행 연구들에서는 혈청 $\mathrm{P}$ 농도 $2.5 \mathrm{mg} / \mathrm{dL}$ 이 하인 환자들에서는 최대흡기압의 감소와 횡격막의 수축력 저하가 나타나고, $1.0 \mathrm{mg} / \mathrm{dL}$ 이하의 환자들에서는 인공호흡기 이탈이 어려 웠으며 P 농도가 정상화되었을 때 증상이 개선되었다는 보고가 있 다 ${ }^{15-17)}$. 한편, 미숙아를 대상으로 한 연구에서는 $2 \mathrm{mg} / \mathrm{dL}$ 미만의 심 한 저인산혈증 환자와 2-4 mg/dL 범위의 중등도 저인산혈증 환자를 비교하였을 때 기계환기 등 임상적 결과에서 통계적으로 유의한 차 이를 보이지 않았다고 보고하고 있다 ${ }^{3)}$. 본 연구에서도 생후 1 주일간 최소 $\mathrm{P}$ 수치가 $2 \mathrm{mg} / \mathrm{dL}$ 미만인 군과 $2 \mathrm{mg} / \mathrm{dL}$ 이상인 군을 나누어 생 후 2 주 침습적 환기 의존도와 중등도 이상의 $\mathrm{BPD}$ 를 비교하였을 때 유의한 차이를 보이지 않았다.

미숙아들의 생후 초기 1 주일간 $\mathrm{P}$ 를 얼마나 공급하는 것이 이상적 인지에 대해서는 논란이 있다. 여러 가이드라인들에서 미숙아의 P 공급 권장량을 제시하고 있지만, 실제 임상적으로 적용 시에 제한점 이 많다. 유럽경장영양학회(European Society for Clinical Nutrition and Metabolism) 가이드라인에서는 Ca 2.0-8.0 mEq/kg/day, P $0.75-3.0 \mathrm{mM} / \mathrm{kg} / \mathrm{day}$ 를 1:3-1:7의 몰 $(\mathrm{mol})$ 비율로 공급하도록 권장 하고 있지만 ${ }^{18)}$ 생후 초기 1주일에 권장 공급량을 그대로 적용 시 고 칼슘혈증, 저인산혈증과 같은 전해질 불균형이 발생한다는 보고들 이 많다 ${ }^{19)}$. 본 연구 대상 환자들에서 공급된 생후 1 주일 $\mathrm{Ca} / \mathrm{P}$ 몰 비 율은 $1.43: 1$ 이었으며, 1 주일 평균 $\mathrm{Ca}$ 공급량은 $1.4 \mathrm{mEq} / \mathrm{kg} / \mathrm{day}, \mathrm{P}$ 공급량은 $0.6 \mathrm{mM} / \mathrm{kg} / \mathrm{day}$ 로 가이드라인에서 제시하는 권장량에 미 치지 못하였다. 미숙아는 생후 초기 2-3일간 적정 소변량이 확보되 기 전까지 $\mathrm{Na}$ 과 $\mathrm{K}$ 를 제한하기 때문에 인산염의 형태로 공급되는 $\mathrm{P}$ 또한 공급에 제한이 있으며, 초기 수액 제한(volume restriction)과 침전 생성의 우려로 인한 $\mathrm{Ca}$ 과 $\mathrm{P}$ 의 농축 제한으로 가이드라인에서 제시하는 $\mathrm{Ca}$ 과 $\mathrm{P}$ 의 권장 공급량을 충족시키기 어려운 경우가 많다. 최근의 한 연구에서는 미숙아에서 $\mathrm{Ca}$ 와 아미노산의 공급량을 고려 하여 생후 초기 P 공급량을 설정하도록 제안하고 있다 ${ }^{12)}$. 본 연구는 후향적 연구의 한계로 high P 공급군에서도 P 공급량이 권장량에 비 해 충분하지 못하였고, 미숙아에서 임상적으로 의미 있는 적정한 $\mathrm{P}$ 공급량에 대해서는 전향적 연구가 필요할 것으로 사료된다.

$\mathrm{P}$ 공급량에 따른 두 군의 비교에서 high P 공급군의 높은 재태 연 령이 호흡부전의 예후에 유리하게 작용했을 가능성이 있다. 또한, high P 공급군에서 더 높은 열량과 단백질 공급이 이루어져 영양적
인 측면에서도 더 양호하였다. 이에 다변량 분석에서 재태 연령과 평균 열량 및 단백질 공급량을 공변량(covariate)으로 포함함으로써 이를 보정하고자 하였다. 5분 Apgar score, 제왕절개, 융모양막염, 폐계면활성제 사용, $\mathrm{PDA}$ 치료 여부, 신기능 등의 여러 임상적인 인 자를 보정한 경우에도 P 공급량은 미숙아의 호흡곤란과 유의한 연 관성을 나타내었다. 또한, high P 공급군에서 생후 1 일 내 기계환기 를 적용한 환자의 비율이 낮았는데, 기저 기계환기 의존도를 유사한 조건으로 비교하기 위해 생후 1 일 내 기계환기를 적용한 환자를 대 상으로 하위그룹 분석을 시행하였으며, 하위그룹 분석에서도 P 공 급량은 미숙아의 호흡곤란과 유의한 연관성을 나타내었다.

한편, high P 공급군에서 평균 P 공급량이 low P 공급군의 두 배 이상이었으나, high P 공급군에서 최저 혈청 P 농도와 평균 P 농도가 오히려 낮게 나타나 $\mathrm{P}$ 의 공급량과 혈청 레벨의 괴리를 보여주고 있 으며 이는 refeeding syndrome에서 보이는 것과 유사한 현상으로 이 해할 수 있다. 즉, 상대적으로 재태 연령이 높았던 high P 공급군에 서 거대영양소에 대한 tolerance가 양호하여 low P 공급군보다 높은 열량과 단백질 공급이 가능했고 $\mathrm{P}$ 가 조직의 동화작용에 이용되면 서 혈청 레벨이 감소한 것일 수 있다. 실제로 본 연구에서도 단백질 공급량과 평균 P 농도가 유의한 음의 상관관계를 나타내었다. 또한, low P 공급군에서 생후 4-7일 기간의 최대 serum creatinine 수치가 high P 공급군에 비해 높게 나타나, 신기능이 저하로 인해 상대적으 로 P 농도가 상승하였을 것으로 사료된다.

초기 단백질 공급량은 $\mathrm{Ca} / \mathrm{P}$ 의 항상성(homeostasis)에 영향을 미 쳐 단백질 공급량이 많을 경우 $\mathrm{P}$ 필요량이 증가될 수 있다 ${ }^{12)}$. 본원 신 생아중환자실에서는 초기 단백질을 고용량 $(3.0 \mathrm{~g} / \mathrm{kg} / \mathrm{day})$ 으로 공급 하지 않고 $1.5-2.0 \mathrm{~g} / \mathrm{kg} / \mathrm{day}$ 로 시작하여 점차 증량하는 방식을 적용 하였다. 그런데도 본 연구 대상 환자들에서 잦은 저인산혈증이 관찰 되었던 것을 감안하면, ELBWIs에서 초기 저인산혈증이 단순히 영양 재개에 의한 동화작용의 촉진에서 기인한 현상으로만 보기는 어려 울 것으로 생각된다. 또 다른 중요한 요인으로서 미숙아의 절대적인 $\mathrm{P}$ 저장량 부족과 절대적인 공급량의 부족이 문제가 될 수 있을 것으 로 사료된다.

79명의 미숙아를 대상으로 시행한 출생 초기 $\mathrm{Ca} / \mathrm{P}$ 대사 연구에서 는 P의 신장 재흡수율(renal tubular reabsorption)은 출생 후 9일까 지 $95 \%$ 이상을 유지하다가 $\mathrm{P}$ 의 추가적인 보충이 이루어진 출생 2 주 째부터 $70 \%$ 이하까지 떨어졌다고 보고하였다 ${ }^{19)}$. 이러한 결과를 토 대로 생후 1 주일 동안 미숙아에서 체내 $\mathrm{P}$ 를 보존하는 보상기전이 이 루어짐을 알 수 있으며, 이런 기전에도 불구하고 저인산혈증이 발생 했다는 점은 체내 $\mathrm{P}$ 의 고갈 때문이라고 생각할 수 있다. 여러 선행 연구들에서 혈청 $\mathrm{P}$ 레벨을 기준으로 임상적 결과와의 상관성을 분 석하였으나 ${ }^{3,15-17)}$, 향후 P 공급량을 기준으로 한 연구가 더 많이 되어 야 할 것으로 사료된다.

본 연구의 한계점은 후향적 연구로, 혈액학적 검사 결과가 일정하 
게 자주 수행되지 못하였고, 저인산혈증 발생의 주요 요인 중 하나인 신장손실을 평가하기 위한 소변 전해질 양이 수집되지 못하였다. 그 러나, ELBWIs를 대상으로 생후 2주 및 postmenstrual age 36주에서 의 호흡기 관련 임상적 결과에 영향을 미칠 수 있는 P 공급량을 제시 하였다는 데 의의가 있다.

결론적으로, ELBWIs에서 생후 1주일간 P 공급량은 생후 2주 침습 적 기계환기 및 중등도 이상의 $\mathrm{BPD}$ 발생에 유의한 영향을 미칠 수 있다. P 공급량 증가 시 미숙아의 호흡곤란의 예방에 효과가 있을 것 으로 기대되므로, ELBWIs의 정맥영양 계획 시 $\mathrm{P}$ 의 요구량이 증가될 수 있는 요인들을 고려하여 충분히 공급하는 것을 추천한다.

이해관계

본 저자는 이 논문과 관련된 이해관계가 없음.

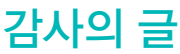

이 논문은 2017년도 정부(교육부)의 재원으로 한국연구재단의 지원 을 받아 수행 된 기초연구사업임(No. NRF-2017R1D1A1B04030931).

\section{REFERENCES}

1. Ichikawa G, Watabe Y, Suzumura H, Sairenchi T, Muto T, Arisaka O. Hypophosphatemia in small for gestational age extremely low birth weight infants receiving parenteral nutrition in the first week after birth. J Pediatr Endocrinol Metab 2012;25:317-21.

2. Boubred F, Herlenius E, Bartocci M, Jonsson B, Vanpee M. Extremely preterm infants who are small for gestational age have a high risk of early hypophosphatemia and hypokalemia. Acta Paediatr 2015;104:1077-83.

3. Brener Dik PH, Galletti MF, Fernandez Jonusas SA, Alonso G, Mariani GL, Fustinana CA. Early hypophosphatemia in preterm infants receiving aggressive parenteral nutrition. J Perinatol 2015;35:712-5.

4. Rustico SE, Calabria AC, Garber SJ. Metabolic bone disease of prematurity. J Clin Transl Endocrinol 2014;1:85-91.

5. Ross JR, Finch C, Ebeling M, Taylor SN. Refeeding syndrome in very-low-birth-weight intrauterine growth-restricted neonates. J Perinatol 2013;33:717-20.

6. Geerse DA, Bindels AJ, Kuiper MA, Roos AN, Spronk PE, Schultz MJ. Treatment of hypophosphatemia in the intensive care unit: a review. Crit Care 2010;14:R147.
7. Amanzadeh J, Reilly RF Jr. Hypophosphatemia: an evidencebased approach to its clinical consequences and management. Nat Clin Pract Nephrol 2006;2:136-48.

8. Kim JW. Refeeding syndrome. J Clin Nutr 2015;7:15-22.

9. Shor R, Halabe A, Rishver S, Tilis Y, Matas Z, Fux A, et al. Severe hypophosphatemia in sepsis as a mortality predictor. Ann Clin Lab Sci 2006;36:67-72.

10. Van Kempen TA, Deixler E, Crook MA. Hypophosphatemia as a key factor in sudden infant death syndrome (SIDS)? Ups J Med Sci 2013;118:143-4.

11. Moltu SJ, Strommen K, Blakstad EW, Almaas AN, Westerberg AC, Braekke K, et al. Enhanced feeding in very-low-birth-weight infants may cause electrolyte disturbances and septicemia: a randomized, controlled trial. Clin Nutr 2013;32:207-12.

12. Bonsante F, Iacobelli S, Latorre G, Rigo J, De Felice C, Robillard PY, et al. Initial amino acid intake influences phosphorus and calcium homeostasis in preterm infants: it is time to change the composition of the early parenteral nutrition. PLoS One 2013;8: e72880.

13. Fenton TR, Kim JH. A systematic review and meta-analysis to revise the Fenton growth chart for preterm infants. BMC Pediatr 2013;13:59.

14. Ehrenkranz RA, Walsh MC, Vohr BR, Jobe AH, Wright LL, Fanaroff AA, et al. Validation of the National Institutes of Health consensus definition of bronchopulmonary dysplasia. Pediatrics 2005;116:1353-60.

15. Gravelyn TR, Brophy N, Siegert C, Peters-Golden M. Hypophosphatemia-associated respiratory muscle weakness in a general inpatient population. Am J Med 1988;84:870-6.

16. Aubier M, Murciano D, Lecocguic Y, Viires N, Jacquens $Y$, Squara $\mathrm{P}$, et al. Effect of hypophosphatemia on diaphragmatic contractility in patients with acute respiratory failure. $\mathrm{N}$ Engl J Med 1985;313:420-4.

17. Brown EL, Jenkins BA. A case of respiratory failure complicated by acute hypophosphataemia. Anaesthesia 1980;35:42-5.

18. Koletzko B, Goulet O, Hunt J, Krohn K, Shamir R; Parenteral Nutrition Guidelines Working Group, et al. Guidelines on pediatric parenteral nutrition of the European Society of Pediatric Gastroenterology, Hepatology and Nutrition (ESPGHAN) and the European Society for Clinical Nutrition and Metabolism (ESPEN). Iron, Minerals, and Trace Elements. J Pediatr Gastroenterol Nutr 2005;41(Suppl 2):S39-46.

19. Christmann V, Gradussen CJ, Kornmann MN, Roeleveld N, van Goudoever JB, van Heijst AF. Changes in biochemical parameters of the calcium-phosphorus homeostasis in relation to nutritional intake in very-low-birth-weight infants. Nutrients 2016;8:E764. 